\title{
Distribution of Major Tef Diseases in Central Highland Area of Ethiopia
}

\author{
Yitagesu Tadesse*, Niguse Belay, Dereje Amare, Asela Kesho, Getahun Bekana
}

Holleta Agricultural Research Centre, Ethiopian Institute of Agricultural Research, Addis Ababa, Ethiopia

Email address:

tyitagesu4@gmail.com (Y. Tadesse)

${ }^{*}$ Corresponding author

\section{To cite this article:}

Yitagesu Tadesse, Niguse Belay, Dereje Amare, Asela Kesho, Getahun Bekana. Distribution of Major Tef Diseases in Central Highland Area of Ethiopia. International Journal of Applied Agricultural Sciences. Vol. 7, No. 3, 2021, pp. 135-137. doi: 10.11648/j.ijaas.20210703.14

Received: March 25, 2021; Accepted: May 6, 2021; Published: June 22, 2021

\begin{abstract}
Tef (Eragrostis tef (Zucc.) Trotter), is the major Ethiopian cereal crop which feed peoples The prevalence and damage inflicted by diseases and insect pests varies from region to region and shows large seasonal variation, the current status of diseases is generally little known. Information on the prevalence and status of diseases would be essential to devise sound management options. So, our objective is to assess the status of major tef foliar diseases in central highland area of Ethiopia. Assessment was carried in the major tef producing districts of West Shewa, South-west and North shewa zones of Ethiopia. The assessment done in 2019/2020 main cropping season along the main roads and accessible routes in each survey district, and stops made at every $5-10 \mathrm{~km}$ intervals based on vehicles odometers as per tef fields available. We have assessed 35 fields which have the potential to produce tef from three zones. From our assessment the major tef foliar diseases recorded were leaf rust, head smudge and spot blotch. The highest tef leaf rust severity (90S) recorded in north shewa zone Mendida district where as the lowest $(0 \%)$ recorded in Awaro, Asgori, woliso and Dendi districts from South west shewa zone. The highest head smudge severity recorded in west shewa zone liben jawe district where as the lowest head smudge severity recorded in woliso, wolimera and tokekutaye district. There is no head smudge disease recorded in north shewa zone. From our assessment, we have concluded that tef leaf rust and head smudge are the most economically important diseases. Therefore, it is very crucial to develop management option to mitigate those diseases.
\end{abstract}

Keywords: Eragrostis Tef (Zucc.) Trotter, Disease Survey, Tef Leaf Rust and Head Smudge

\section{Introduction}

Tef, Eragrostis tef (Zucc.) Trotter, is the major Ethiopian cereal grown on about 3 million hectares annually, and serving as staple food grain [1]. It was estimated that tef made up to $24 \%$ of all the cultivated area in Ethiopia, covering about 3.08 million hectares and grown by 6.78 million farmers [2]. It is primarily used for human consumption after baking the grain flour into popular cottage bread called "injera". The straw (chid) is an important source of feed for animals [3]. Tef is also a resilient crop adapted to diverse agro-ecologies with reasonable tolerance to both terminal drought and waterlogging moisture stresses. Tef, therefore, is useful as a low-risk crop to farmers due to its high potential of adaption to climate change and fluctuating environmental conditions [4].

The continued cultivation of tef in Ethiopia is accentuated by the following relative merits: 1) as the predominant crop, tef is grown in a wide array of agro-ecologies, cropping systems, soil types and moisture regimes [5]; 2) with harvests of 4.75 million tons of grain per year from about 3 million ha, tef constitutes about $30 \%$ of the total acreage and $20 \%$ of the gross yearly grain production of cereals in Ethiopia followed by maize which accounts for about $21 \%$ of the acreage and $31 \%$ of the overall cereal grain production $[2,6] ; 3)$ the values of the grain and straw contribute more than four billion USD to the national GDP [7]; 4) it has a good export market, although domestic grain price hikes had at times led to food grain export ban [8]; 5) tef grain has got relatively good nutritive value especially since it contains relatively high amounts of iron, calcium and copper compared to other cereals $[9,10]$. Because of its gluten-free proteins and slow release carbohydrate constituents, tef is recently being advocated for and promoted as health crop at the global level [11]. 
The national yield per unit area (1.76 t/ha) still remains low [2], quite large proportions of tef producing farmers still use unimproved local cultivars, bottleneck problems like lodging have not been alleviated, age-old traditional tef cultivation and processing methods are being used, and the demand for high-quality tef planting seed has become increasingly high. On the other hand, nutritional and end-use quality research, and the use of machinery has not been pursued to the extent that tef cultivation deserves it [12].

A number of disease pathogens [13] and insect pests [14] are known to attack tef, although the crop is said to be relatively healthy crop as compared to most other crops. Some of the diseases such as leaf rust (Uromyces eragrostidis Tracy), head smudge (Helmithosporium miyakei Niskado) and damping off (Dreschlera spp.) have been listed among the most important species in different areas particularly in the west and south west parts of the country [15]. The prevalence and damage inflicted by these diseases and insect pests varies from region to region and shows large seasonal variation, the current status of tef diseases is generally little known. Information on the prevalence and status of pests would be essential to devise sound management options. So our objective was to assess the status of major tef diseases in central highland part of Ethiopia.

\section{Materials and Methods}

Disease surveys was carried out in the major tef producing districts of North, South-west and West Shewa zones of Amhara and Oromia regional states. Survey districts in each zone selected based on tef area coverage. The survey carried out in 2019/2020 main cropping season (from October to November) along the main roads and accessible routes in each survey district, and stops made at every $5-10 \mathrm{~km}$ intervals based on vehicles odometers as per tef fields available. Depending on the size of the field, 5-10 spots in quadrant $(2 \mathrm{~m} \times 2 \mathrm{~m})$ assessed in each field in "W" orientation. A total of 35 tef fields assessed from three tef producing zones.

Table 1. Status of Major Tef Diseases in Central Highland Areas of Ethiopia.

\begin{tabular}{|c|c|c|c|c|c|c|c|c|}
\hline Zone & Woreda & $\begin{array}{l}\text { No. of Fields } \\
\text { assessed }\end{array}$ & LR Incidence & Lr severity & $\begin{array}{l}\text { Head smudge } \\
\text { Inc. }\end{array}$ & $\begin{array}{l}\text { Head smudge } \\
\text { Severity }\end{array}$ & $\begin{array}{l}\text { Spot Botch / } \\
\text { Panicle Blast } \\
\text { Inc. }\end{array}$ & $\begin{array}{l}\text { Spot Blotch / } \\
\text { Panicle Blast } \\
\text { Severity }\end{array}$ \\
\hline \multirow{8}{*}{ West Shewa } & Liben Jawe & 2 & $25-70$ & $15 \mathrm{MS}-40 \mathrm{~S}$ & $0-20$ & $0-20$ & $40-60$ & $20-30$ \\
\hline & Tokekutaye & 3 & $20-30$ & 5MR-15MS & $0-25$ & $0-25$ & $20-40$ & $5.0-15$ \\
\hline & Awaro & 1 & 0 & 0 & 50 & 50 & 10 & 5 \\
\hline & Asgori & 1 & 0 & 0 & 5 & 5 & 40 & 15 \\
\hline & Dendi & 2 & 0 & 0 & $10.0-15$ & $10.0-15$ & $40-100$ & $5.0-80$ \\
\hline & Ejere & 2 & $5.0-40$ & tr-10MS & $5.0-20$ & $5.0-20$ & $15-25$ & $5.0-10$ \\
\hline & Wolimera & 3 & $0-50$ & $0-25 \mathrm{MS}$ & $0-10$ & $0-10$ & $0-15$ & $0-5$ \\
\hline & Mean/Range & 14 & $0-70$ & $0-40 \mathrm{~S}$ & $0-75$ & $0-75$ & $0-100$ & $0-80$ \\
\hline \multirow{4}{*}{ South west Shewa } & Woliso & 3 & 0 & 0 & 0 & 0 & $10.0-80$ & $10.0-50$ \\
\hline & Becho & 3 & $0-60$ & $0-50 \mathrm{~S}$ & $0-15$ & $0-15$ & $0-60$ & $0-25$ \\
\hline & Sebeta Hawas & 3 & $50-90$ & $25 \mathrm{MS}-60 \mathrm{~S}$ & $0-30$ & $0-30$ & 0 & 0 \\
\hline & Mean/Range & 9 & $0-90$ & $0-60 \mathrm{~S}$ & $0-30$ & $0-30$ & $0-80$ & $0-50$ \\
\hline \multirow{9}{*}{ North Shewa } & Jiru & 1 & 20 & $15 \mathrm{MS}$ & 0 & 0 & 15 & 10 \\
\hline & Siya Debir & 4 & $15-100$ & $5 \mathrm{R}-80 \mathrm{~S}$ & 0 & 0 & 0 & 0 \\
\hline & Mendida & 2 & 100 & $60 \mathrm{~S}-90 \mathrm{~S}$ & 0 & 0 & 0 & 0 \\
\hline & Sheno & 1 & 100 & $50 \mathrm{~S}$ & 0 & 0 & 0 & 0 \\
\hline & Basonawerena & 1 & 60 & $30 \mathrm{~S}$ & 0 & 0 & 0 & 0 \\
\hline & Angolelanatara & 1 & 40 & $20 \mathrm{MS}$ & 0 & 0 & 0 & 0 \\
\hline & Alelitu & 2 & $0-10$ & $0-\operatorname{tr}$ & 0 & 0 & $0-20$ & $0-5$ \\
\hline & Mean/Range & 12 & $0-100$ & $0-90 \mathrm{~S}$ & 0 & 0 & $0-20$ & $0-10$ \\
\hline & Total & 35 & & & & & & \\
\hline
\end{tabular}

\section{Result and Discussion}

\subsection{Major tef Diseases Incidence}

In west Shewa zone the highest leaf rust incidence $40-70 \%$ at Ejere, Liben jawe \& Wolemera districts; whereas the lowest $0 \%$ was recorded at Aware, Asgore \& Dendi districts respectively. The highest head smudge incidence $20-75 \%$ at Tokekutaye, Awaro \& Asgori districts; whereas the lowest $0-20 \%$ was recorded at Liben Jawe, Ejere \& Dendi districts respectively.

In South-west Shewa zone the highest leaf rust incidence $50-90 \%$ at Bcho \& Sebeta Hawas districts; whereas the lowest $0 \%$ was recorded at Woliso district respectively. The highest leaf rust severity $25 \mathrm{MS}-60 \mathrm{~S} \%$ at Bcho \& Sebeta
Hawas districts; where us the lowest $0 \%$ was recorded at Woliso district respectively.

The highest head smudge incidence $30 \%$ at Sebeta Hawas district; whereas the lowest $0-20 \%$ was recorded at Becho and Woliso districts respectively.

In North Shewa zone the highest leaf rust incidence 40$100 \%$ at Mendida, Siyadebir, Angolelanatera, Sheno \& Angolelanatara districts; whereas the lowest $0 \%$ was recorded at Alelitu district respectively.

\subsection{Major tef Diseases Severity}

In West shewa zone; the highest leaf rust severity $15 \mathrm{MS}-$ $40 \mathrm{~S} \%$ at Liben jawe \& Wolemera districts; where us the lowest $0 \%$ was recorded at Aware, Asgore \& Dendi districts respectively. In South west shewa; the highest head smudge 
severity $30-70 \%$ at Liben jawe, Tokekutayo \& Awaro districts; whereas the lowest $0-30 \%$ was recorded at Wolemra, Ejere \& Dendi districts respectively. The highest head smudge severity $50 \%$ at Sebeta Hawas district; whereas the lowest $0-30 \%$ was recorded at Becho and Woliso districts respectively. In North shewa zone; the highest leaf rust severity $2 \mathrm{MS}-90 \mathrm{~S} \%$ at Mendida, Siyadebir, Angolelanatera, Sheno \& Angolelanatara districts; whereas the lowest $0 \%$ was recorded at Alelitu district respectively. The lowest incidence and seerity- $0 \%$ was recorded at all districts in North shewa zone.

Generally, the highest mean leaf rust severity recorded in North shewa zone whereas the lowest recorded in west shewa zone. The highest tef leaf rust severity (90S) recorded in north shewa zone Mendida district where as the lowest $(0 \%)$ recorded in Awaro, Asgori, woliso and Dendi districts from South west shewa zone. From our assessment the major tef foliar diseases recorded were leaf rust, head smudge and spot blotch.

The highest head smudge severity recorded in west shewa zone liben jawe district where as the lowest head smudge severity recorded in woliso, wolimera and tokekutaye district. There is no head smudge disease recorded in north shewa zone. From our assessment, we have concluded that tef leaf rust and head smudge are the most economically important diseases.

\section{Conclusion and Recommendation}

From our assessment the major tef foliar diseases recorded were leaf rust, head smudge and spot blotch. The highest tef leaf rust severity (90S) recorded in north shewa zone Mendida district where as the lowest $(0 \%)$ recorded in Awaro, Asgori, woliso and Dendi districts from South west shewa zone. The highest head smudge severity recorded in west shewa zone liben jawe district where as the lowest head smudge severity recorded in woliso, wolimera and tokekutaye district. There is no head smudge disease recorded in north shewa zone. We have concluded that tef leaf rust and head smudge are the most economically important diseases. Therefore, it is very crucial to develop management option to mitigate those diseases.

\section{Acknowledgements}

First of all, we would like to thank the Almighty God and St. Marry for making all things possible with their boundless and kind supply of unconditional supports.

\section{References}

[1] Assefa K, Aliye S, Belay G, Metaferia G, Tefera H, Sorrells ME. Quncho: the first popular tef variety in Ethiopia. International Journal of Agricultural Sustainability. 2011 Feb 1; 9 (1): 25-34.
[2] CSA (Central Statistical Authority) (2019). Agriculture Sample Survey 2018/2019 (June, 2019). Report on Area and Production of Major Crops (Private Peasant Holdings, Meher Seasons). Addis Ababa Ethiopia, the FDRE statistical bulletin Volume 01-589.

[3] Tamang JP, Cotter PD, Endo A, Han NS, Kort R, Liu SQ, Mayo B, Westerik N, Hutkins R. Fermented foods in a global age: East meets West. Comprehensive Reviews in Food Science and Food Safety. 2020 Jan; 19 (1): 184-217.

[4] Fikadu A, Wedu TD, Derseh E. Review on economics of teff in Ethiopia. Open Access Biostatistics \& Bioinformatics. 2019; 2: $1-8$.

[5] Assefa K, Ketema S, Tefera H, Nguyen HT, Blum A, Ayele M, Bai G, Simane B, Kefyalew T. Diversity among germplasm lines of the Ethiopian cereal tef [Eragrostis tef (Zucc.) Trotter]. Euphytica. 1999 Mar; 106 (1): 87-97.

[6] Assefa K, Chanyalew S, Metaferia G. Conventional and molecular tef breeding. Tef Improvement. 2011 Nov 7: 33.

[7] Chemeda G, Birhanu C, Mengistu G, Lule D, Bedada G, Dessalegn K, Mamo K, Kebede M, Debela M, Anbesa F. Grain yield stability and agronomic performance of tef genotypes in western Oromia. In Oromia Agricultural Research Institute, Workshop proceeding for completed research activities of Adaptation and Generation of Agricultural Technologies 2017 (p. 24).

[8] Tadele Z. Solomon Chanyalew, Setotaw Ferede, Tebkew Damte, Tsion Fikre, Yazachew Genet, Worku Kebede, Kidist Tolossa. Planta. 2019; 250: 753-67.

[9] Ronda F, Abebe W, Pérez-Quirce S, Collar C. Suitability of tef varieties in mixed wheat flour bread matrices: A physicochemical and nutritional approach. Journal of Cereal Science. 2015 Jul 1; 64: 139-46.

[10] Satheesh N, Fanta SW. Review on structural, nutritional and anti-nutritional composition of Teff (Eragrostis tef) in comparison with Quinoa (Chenopodium quinoa Willd.). Cogent Food \& Agriculture. 2018 Jan 1; 4 (1): 1546942.

[11] Lule D, Chemeda G, Birhanu C. Registration of "Dursi" Newly Released Tef (Eragrostis tef (Zucc.) Trotter) Variety. Ethiopian Journal of Crop Science. 2019; 7 (1).

[12] Barretto R, Buenavista RM, Rivera JL, Wang S, Prasad PV, Siliveru K. Teff (Eragrostis tef) processing, utilization and future opportunities: a review. International Journal of Food Science \& Technology. 2020 Nov 22.

[13] Badebo A. 14. Pathological Research in Tef. Tef Improvement.: 193.

[14] Damte T. 13. Insect Pest Management Research in Tef. Tef Improvement.: 171.

[15] Ashenafi Gemechu, Kebebew Assefa, Yazachew Genet and Tsion Fikre. Status of Tef (Eragrostis tef) Diseases in Ethiopia. Agri Res \& Tech: Open Access J. 2018; 17 (3): 556026. DOI: 10.19080/ARTOAJ.2018.17.556026. 